\title{
Patchworking Response-ability in Science and Technology Education
}

\author{
Marc Higgins, Assistant Professor, University of Alberta, e-mail marc.higgins@ualberta.ca \\ Blue Mahy, Independent scholar, e-mail blue.mahy@monash.edu \\ Rouhollah Aghasaleh, Postdoctoral Research Associate, Georgia State University, e-mail \\ raghasaleh@gsu.edu \\ Patrick Enderle, Assistant Professor, Georgia State University, e-mail penderle@gsu.edu
}

\section{Abstract}

Within science and technology education, concepts of justice, in/equity, and ethics within science education are simultaneously ubiquitous, necessary, yet un(der)theorized. Consequently, the potential for reproducing and reifying systems of power remains ever present. In response, there is a recent but growing movement within science and technology education that follows the call by Kayumova and colleagues (2019) to move "from empowerment to response-ability." It is a call to collectively organize, reconfigure, and reimagine science and technology education by taking seriously critiques of Western modern science and technology from its co-constitutive exteriority (e.g., feminist critiques). Herein, we pursue the (re)opening of responsiveness with/in methodology by juxtaposing differential, partial, and situated accounts of response-ability: de/colonizing the Anthropocene in science teacher education in Canada (Higgins); speculative fiction at the science-ethics nexus in secondary schooling in Australia (Mahy); and a reciprocal model for teaching and learning computational competencies with Latinx youth in the US (Aghasaleh and Enderle).

Keywords: science education; technology education; post-qualitative methodology; post-critical pedagogy

There is no shortage of epistemologies and ontologies (e.g., feminist, [I]ndigenous, African, anticolonial, etc.) which have called attention to and critiqued Western humanism and nature-culture binary thinking; nonetheless, there is a shortage of 
collective organizing, reconfiguring, and reimagining of science curriculum in light of these calls. (Kayumova, McGuire, \& Cardello, 2019, p. 212, emphasis in original)

Responsibility is not a commitment that a subject chooses but rather an incarnate relation that precedes the intentionality of consciousness. (Barad, 2007, p. 392).

We begin this article by echoing Elizabeth Ellsworth's (1989) poignant question Why doesn't this feel empowering? and ask it of science and technology education. Science, technology, and more recently STEM (i.e., science, technology, engineering, and mathematics) education are increasingly being heralded as remedy to a multiplicity of contemporary issues (e.g., scientific literacy) and are actively worked upon in order to be more accessible, inclusive, and empowering (Chesky \& Wolfmeyer, 2015). Yet, as Kayumova and colleagues (2019) suggest of science education, this is often done without heeding critical calls that invite consideration of the ways in which science, and in turn STEM education, are premised upon the Othering of Nature and those "closer to nature" via nature-culture binary thinking (see also Aghasaleh, 2019a; Bang \& Marin, 2015; Higgins \& Kim, 2018; Wallace, 2018). As a result, the concepts of justice, in/equity, and ethics within science education are simultaneously ubiquitous, necessary, yet un(der)theorized: science and technology education thus becomes a panacea that cannot account for or be accountable to the ways in which it is (always already) a poison (Tolbert \& Bazzul, 2017; Lupinacci \& Wolfmeyer, 2018; Wolfmeyer \& Lupinacci, 2017). Consequently, the potential for reproducing and reifying systems of power remains ever present, be it at the level of policy (e.g., Bullock, 2017; Daza, 2013; Wolfmeyer \& Chesky, 2015), curriculum and pedagogy (e.g., Cedillo, 2018; Heybach \& Pickup, 2017; Higgins, 2019; McKinley, 2001), or research practice (e.g., Chen \& Buell, 2018; Higgins, Wallace, \& Bazzul, 2018; Kayumova, Zhang, \& Scantlebury, 2018).

In response, there is a recent but growing movement within science and technology education that follows the call by Kayumova and colleagues (2019) to move "from empowerment to response-ability" (e.g., deFreitas, Lupinacci, \& Pais, 2017; Higgins \& Tolbert, 2018; Wallace, Higgins, \& Bazzul, 2018; Verlie, 2017). In short, response-ability is "an ability to respond, to respond to the world beyond oneself, as well as a willingness to recognize its existence" (Kuokkanen, 2007, p. 39). As a (post-)critical concept, response-ability is more than the simple taking up of responsibility towards the Other: as responsibility is "an incarnate relation that precedes the intentionality of consciousness" (Barad, 2007, p. 392). In science and technology education, this "incarnate relation" specifically necessitates a critical consideration of its logics of Othering that render the responsibilities which we already have (and by which we are shaped) inert. For example, in science education, this Othering takes the shape of (un)making "science people" through the double(d) process in which some become scientific while others become non- or less scientific (Wallace, 2018). The oft depoliticized and atheoretical work of inclusion continues to Other peoples, practices, and places previously excluded, albeit differentially. These binary logics shape the (in)ability to respond but also the ways in which we are always already in co-constitutive relation; these logics are both sites of problematics and possibilities of the past, the present, and of the futures we must speculate and imagine otherwise. Response-ability invites a creative 
and critical working within and against without succumbing to the fantasy of transcending that which we work against (Haraway, 2016; Higgins, Wallace, Bazzul, 2019): particularly by taking seriously Kayumova and colleagues' (2019) call to collectively organize, reconfigure, and reimagine science and technology education by taking seriously critiques of Western modern science and technology from its coconstitutive exteriority (e.g., feminist theories). Notably, it is a call to think with, not for, those who are Othered by the material-discursive practices of science and technology education as a means of (re)opening the ability to respond; as well as one to think within and against the systems that make such lines of inclusion/exclusion possible. Whereas response-ability is making an appearance most frequently in science and technology education via the work of feminist technoscience scholars Karen Barad (e.g., 2010) and Donna Haraway (e.g., 2016), we want to note the significance of response-ability productively taking differing shapes should we approach it via other theoretical approaches such as post-colonialism (e.g., Spivak, 1994) or Indigenous ways-of-knowing-in-being (e.g., Kuokkanen, 2007) ${ }^{1}$. Importantly, for science and technology education to be response-able, it must do its "homework" (Kuokkanen, 2007): it must simultaneously (learn to) learn from the very ways-of-knowing-in-being it Others as well as differentially come-to-know itself in the process (Kayumova et al., 2018; Higgins \& Tolbert, 2018).

Within this paper, we pursue response-ability in science and technology education: engaging in the iterative labour of (re)opening and re(con)figuring the possibilities and problematics of responsiveness towards the relationships of Otherness that always already constitute our being and becoming. In (re)presenting our differential accounts we re- and un-weave together methodological threads to create a patchwork that disperse and deploy contingent and situated making-withs (see Haraway, 2016). Specifically, we employ patchwork(ing) methodologies to (re)present this work (Higgins, Madden, Bérard, Lenz Kothe, \& Nordstrom, 2017)². Inspired by Jackson \& Mazzei's $(2012,2013,2017)$ Thinking with Theory, patchwork(ing) methodologies "are nebulous, responsive, contingent, and shifting methodologies that move with fragments that produce possibilities" (Higgins et al., 2017, p. 18). Pathchwork(ing), both product and process, begins from the recognition that the methodological or pedagogical fabric at hand is a fabrication and thus open to become otherwise through reworking the (co-)constitutive threads: be they already at hand within the practice, those differed and deferred, as well as those never intended for them in the first place (see Higgins et al., 2018). Patchwork(ing) invites attention to the ways in which methodologies can be differentially (un)done should we attend to the threads already present and those not-yet or yet-to-come: pulled together, apart, elsewhere, in and out to produce new configurations of theory-practice-ethics. Patchwork(ing) methodologies respond to the ways in which received understandings suture over possibilities for justice-to-come and labours to

\footnotetext{
${ }^{1}$ See Higgins (2017), in this journal, for a lengthier discussion on diffracting differential framings of response-ability, and the post-qualitative potentialities made possible through reading one through another.

2 Thank you to a reviewer for the insightful comment that all research and writing is always already a patchwork, even if the academy conventionally values the patchwork that appears as "tailored": representationally, this text honours this by leaving some loose and dangling threads in plain sight as multiplicitous invitations and potential connectivities rather than flaws or deficits to be corrected (in order to present and pre-empt a correct reading).
}

Reconceptualizing Educational Research Methodology 2019, 2,3(2) Special Issue https://journals.hioa.no/index.php/rerm/issue/view/397 
(re)open these excessive potentialities by attending to the stitched-over meanings that are absently present or by mending methodology with matters and meanings presently absent. As such, they offer ways of pursuing response-ability in science education and technology where many lingering referents of power problematically lurk under the form of taken-for-granted notions of equity, accessibility, and empowerment (Higgins et al., 2018; McKinley, 2001). Further, such a methodological re(con)figuration works beyond individualistic responses, not only recognizing that a single theory could ever account for or be ethically accountable to the co-constitutive relations at play, but also that no individual researcher could wholly undo the ways in which in/equity persist in science and technology education.

Patchwork(ing) methodologies takes this multiplicity seriously by juxtaposing partial and situated accounts (rather than impossibly full) in hopes that the interwoven sum might come to be greater than the parts. Within these vignettes, we each explore the work of (re)opening the ability to respond within our own unique contexts and commitments: de/colonizing the Anthropocene in science teacher education in Canada (Marc); the science-ethics nexus in secondary schooling in Australia (Blue); and a reciprocal model for teaching and learning computational competencies with Latinx youth in the US (Rouhollah and Patrick). Representationally, this work is presented in four "threads": (1) the theory/theorist(s) with whom we are thinking with; (2) describing further the contexts to which we responsible; (3) our methodological or pedagogical re- and un-weaving with theory towards new forms of response-ability; as well as, (4) a glimpse at what such entanglement (speculatively might) produce(s). Below is a glimpse at the tangles being juxtaposed. These accounts are differentially voiced as there is not $a$ voice or $a$ perspective from which an address can or should be given over; further, they are partial because it would be impossible to give more than an account of our attempts to weave in ethical commitments but also in that we deliberately create a patchwork(ing) of our attempts that is more than the sum of its parts, an incomplete critical collectivity(-to-come).

\section{Thread 1 - Theory/Theorist}

\section{Thread 1 - Marc: De/colonizing science education's response-ability to the Anthropocene with Indigenous Science and Technology Studies}

If one of the reasons the natural and social sciences and humanities have turned to the figure of the Anthropocene is because it describes a condition in which current ways of life (human and otherwise) are no longer able to continue their recent path, then concepts of politics and polity based in those ways of life also will change.

(Liboiron, Tironi, \& Calvonni, 2018, p. 343)

I am increasingly interested in the question of whether or not we can address the Anthropocene within science education: this new "geological epoch ...in which human activities came to have a major influence on the earth's physical processes" (Gilbert, 2016, p. 188). Science education has a responsibility, but is it able to respond? As Gilbert (2016) argues, science education's forces and flows 
render its more critical dimensions (e.g., Science, Technology, Society, and Environment [STSE]) inert through rendering them epistemological objects: teaching about them rather than with and through them in ways that implicate learners. I recognize that science education has barely begun to respond, to be able to respond, to the Anthropocene. Yet, simultaneously, as a white settler scholar in Canada whose primary research orientation is one of de/colonizing, I cannot ignore the calls for decolonizing the Anthropocene.

Here, I understand a de/colonizing orientation as one which strives towards the goals of decolonization while recognizing that colonization and decolonization cannot be framed neatly in opposition from one another. This is particularly significant in educational institutions (of which many are on stolen Indigenous land in North American contexts; see Kuokkanen, 2007), research positionalities (e.g., white settlers like myself) and fields (such as science education), whose complex material-discursive structures, commitments, and practices make it such that (neo-)colonial logics and productions seep into attempts to resist them (see Higgins \& Kim, 2018; Higgins \& Tolbert, 2018; Higgins, 2019).

To take seriously de/colonizing alongside teaching for (rather than about) the Anthropocene invites a taking up the work of Indigenous Science, Technology, and Society (STS) scholars who suggest that the Anthropocene is but one of many. Or, as Davis and Todd (2016) invite us to consider, "if the Anthropocene is already here, the question then becomes, what can we do with it as a conceptual apparatus that may serve to undermine the conditions that it names?" (Davis \& Todd, 2016, p. 763). The current Anthropocene is premised upon a multiplicity of similar moments that must be considered in tandem (e.g., the "Orbis spike" of 1610 [Lewis \& Maslin, 2015] in which atmospheric $\mathrm{CO}_{2}$ levels drastically dropped as a result of the genocide of Indigenous peoples). By extension, that Anthropocene(s) could and should be considered an extension of (neo-)colonial logics and practices (see Davis \& Todd, 2016; Whyte, 2018). For example, the way in which all humans are held equally responsible under the signifier that is "anthropos" gestures towards a universalizing image of Man who must respond framed outside of or beyond the capitalist and (neo-)colonial relations of power through which the Anthropocene came about - "Man" is off the hook for the material (in both Marxist and new materialist sense of the word) and cultural erasure of difference.

Specifically, within this manuscript, in turning to Indigenous STS, I attune to the work of Métis, feminist, anti-colonial, and environmental scientist Max Liboiron who, self-admittedly, has "been working on plastic pollution since before it was cool" (Liboiron, 2019). Particularly, her work on toxic politics inspires responsiveness to the toxic harms of the Anthropocene in ways that refuse and resist simple reproductions of (neo-)colonial logics through "struggles pertaining to power focused on which forms of life are strained or extinguished while other forms reproduce and flourish" (Liboiron et al., 2018, p. 333). Importantly, this entails thinking of toxicity as "a way to describe a disruption of particular existing orders, collectives, materials and relations" (Liboiron et al., 2018, p. 334) - beyond the "settled" understandings of toxicity as badly behaving particles towards expansive natural-cultural re(con)figurations. This could include, for example, disrupting and displacing (neo-)colonial theologies of 
progress relating to the Anthropocene: "we take as our starting point a permanently polluted world" (Liboiron et al., 2018, p. 332).

\section{Thread 1 - Blue: Relational posthumanism}

I call my research framework 'relational posthumanism', which combines together ideas from theorists Karen Barad, Donna Haraway and Rosi Braidotti. While I utilize many of their ideas in my research, in this article I focus on some concepts mainly from Barad and Haraway. Specifically, I consider the interplay between response-ability and relationality, in connection with the Anthropocene, as Marc introduced above. Relationality is inspired by Barad's concept of "intra-action"; that is, the understanding that entities do not ever pre-exist but come to be in relation to each other; or, in other words, via their "ethico-onto-epistemological entanglement", wherein ethics, being and knowing are inseparable (Barad in Kleinmann, 2012, p. 77). The concept of relationality therefore encompasses the combination of these ideas - intra-action and entanglement.

What is at stake in our relational response-ability is how we position research/ourselves in order to develop a more livable world for all, or what Haraway calls "multispecies flourishing" (2016, p. 2). Further, this must be done with particular attention to ongoing power imbalances and relationships of Otherness, such as noted by Marc in terms of decolonizing the Anthropocene. Like Marc, I share a white settler heritage, which makes working towards this goal fraught but necessarily so. This approach therefore connects deeply with the ethical becoming of research.

Further, in terms of positionality, relational posthumanism offers multiple avenues through which to renew understanding of methodology and ethical considerations, beginning with the premise that the becoming of research is a relational entanglement of matter and discourse, as well as ethics and knowledge. This is to consider such aspects of the world as never separate, nor pre-existing each other, but rather what 'becomes' together in the process of research. Theory cannot be separated from practice. This framework connects intrinsically with multiple and dynamic generative approaches to doing research.

In particular, creative practice is one possible renewed methodological venture, offering an alternative relational way in which to (re)conceptualize school science. As a creative approach that especially connects strongly with the science-ethics nexus, I chose the creative practice of speculative fiction as method. This relates to Haraway's 'SF' amalgamation; that is, a practice of threading together science fiction, speculative fabulation, string figures (using strings to make different patterns) and more (Haraway, 2016) in a thinking-feeling-doing process. This process also draws inspiration from Jackson and Mazzei's (2013) 'thinking with theory'.

Speculative fiction has many definitions. The way I defined it for the purposes of my research is fiction that focuses on speculating on the world's (ethical) becoming, as it is now or as it could be, and often with an emphasis on science and technology as powerful forces shaping the world. What speculative 
fiction offers is multiple. It first enacts an entangled becoming of theory, data, ethics, and contexts. It is also a method through which to envision a more livable future for all. In speculative fiction, various binary logics can be denounced and renewed ways of thinking generated. A significant question here is: what might be (re)opened and (re)configured via speculative fiction in relation to school science? As Haraway argues, "It matters what ideas we think other ideas with" (2016, p. 14).

'Relationality' may be a powerful concept at the forefront of discussions around knowledge and research, and a specific ethical gesture of response-ability. This is because it insists on the ongoing entangled becoming of all entities without placing humans-especially white, male humans - at the center, nor does it constrain what ethics is; "We become-with each other or not at all" (Haraway, 2016, p. 4). To challenge the 'static-ness' of settler colonial school science, to acknowledge relationality, and allow for a more livable future to become, it follows that research methods be relational and creative.

\section{Thread 1 - Rouhollah and Patrick: Empowerment as both necessary and rejected}

Herein, we dismantle what has been normalized as college and career readiness through deconstruction of this discourse that both hinder particular expressions of experience and affect, and dehumanize urban Latinx adolescents in learning computational thinking. Lather and St. Pierre (2007) used 'deconstruction' as the general goal for post inquiry. In other words, all post theories like genealogy, archaeology, marginality, performativity, and concepts like assemblage, bodies without organs, intraaction, and others are forms of deconstruction. In this sense, our writing under erasure should be deconstructive. According to Derrida (1990), deconstruction is a way of reading ${ }^{3}$, and it is especially useful when the researcher wants to trouble a normalized, taken-for-granted structure and break it apart. But, more than that, it is an attitude, a way of listening, reading, thinking, and living. We aim to share our experience of working within and against the neoliberal structure that is pervasive, normalized, and at the same time unjust and dangerous. Situated in an after-school program for urban Latinx adolescents designed to enhance students' computational thinking (Wing, 2006) as one of the science and engineering practices recommended by the Next Generation of Science Standards (NGSS, 2013), we explore an entanglement (Barad, 1996) of computer codes, pseudocodes, objects (such as robots, e-textile artifacts, and hardware), and students' bodies. In this entanglement, real material (hardware) and virtual material (software) become extensions of human bodies to create cyborgs (Haraway, 1991). This vignette discusses how this more-than-human ontology provides researchers with an analytical tool to investigate teaching and learning computational thinking by using an "ethico-ontoepistemological" (Barad, 2007) methodology, as Blue introduced it earlier, is becoming a selftransforming genealogy that affirmatively looks into the entanglement between knowing, being and

\footnotetext{
${ }^{3}$ A misconception about post analysis is understanding reading/ writing as merely a discursive act. Obviously, Derrida would reject the discursive/ material binary. The work of post philosophers like Foucault, Deleuze and Guattari, and many other post theorists in science like Haraway, Barad, and Latour imply an emphasis on both discursive and material worlds. For a more extensive discussion on the materiality of language see Bleich (2001) and MacLure (2013).
}

Reconceptualizing Educational Research Methodology 2019, 2,3(2) Special Issue

https://journals.hioa.no/index.php/rerm/issue/view/397 
doing; but with a radical-to-no intervention in oppressive systems. We affirm that "all education is political; teaching is never a neutral act" (Freire, 1968/1972, p. 19) and acknowledge that this analysis (knowing) is grounded in a political standpoint (being) and would lead to activism (doing) (Aghasaleh, Enderle, \& Puvirajah, 2019).

In this analysis we focus on computational thinking, as an "analytic approach to problem solving, designing systems, and understanding human behaviors" (Sengupta, Kinnebrew, Basu, Biswas, \& Clark, 2013, p. 352), which is regarded as a fundamental requirement of all STEM disciplines (Henderson, Cortina, \& Wing, 2007). Wilson, Sudol, Stephenson, \& Stehlik (2010) point out that student participation in computer science education is decreasing in the US while the demand for computer science professionals is increasing dramatically. The lack of qualified computer science teachers and the lack of adequate and appropriate integration of computer science into the school curricula are two important issues discussed in the literature (Barr \& Stephenson, 2011; Goode, 2007, 2008; Grover \& Pea, 2013; Kafai, Fields, \& Burke, 2010).

\section{Thread 2 - Context}

\section{Thread 2 - Marc: De/colonizing science teacher education (in a permanently polluted world)}

Science learning environments are often deeply unreflective of the most pressing scientific questions - rather they focus on "settled" phenomena as well as "settled" perspectives and relations to phenomena. (Bang \& Marin, 2015, p. 531)

In the Canadian context in which I teach, there are growing policy mandates and commitments to take both Indigenous thought and environmentalism seriously (ACDE, 2010, 2018). While these, together, might allow for educational response-ability towards de/colonizing the Anthropocene, there is nonetheless a need to critically inhabit these spaces and deconstructively read them for the complicities which linger and lurk, as Rouhollah and Patrick signal above. Importantly, science teacher education presents itself as an important site in un-settling the doubly settled ways in which we construct and come to understand "what counts" (e.g., as science) in relation to how we got to this Anthropocenic moment as well as what futures we can imagine and how we can work towards them:

Indeed, science and regulation are what define toxicity in dominant discourses and thus are obligatory passage points that must be accounted for when evoking or 
challenging these dominant notions of toxicity or other futures. (Liboiron et al., 2018, p. 336) ${ }^{4}$

The work of unsettling what counts and how it comes to count within science education is not without its challenges: toxic logics often come to shape how we come to understand, and respond to, toxicity. For Wallace (2018), science teacher education is often tied into logics of (un)making "science people": that it legitimates "what counts" as scientific by negatively defining it against that which is deemed unscientific (e.g., through the language of scientific misconception, pseudo-science, or other). In an age in which climate denial often masquerades as science (see Latour, 2004), the critical impetus to differentiate between the two bears some productivity. However, this dichotomizing is directly tied to the (re)production of dominance (including aforementioned colonial, neo-colonial, and capitalist systems) through which, after Bang and Marin (2015), science education remains "settled". That is, the ways in which nature is presented is simultaneously static and (re)producing settler colonial views of the world. In tandem, this "settled" phenomena come to present a view of the world that:

... make the inseparable dynamics of acquisition of land, [I]ndigenous erasure, and the domination of black people appear as an inevitable, unconnected, and natural course of development rather than socio-politically engineered to support and foster white entitlement and privilege. (Bang \& Marin, 2015, p. 532)

Above and beyond the subject of science (education) being shaped by (neo-)colonial logics that (fore)close response-ability, the structure of learning within science teacher education makes it such that teaching and learning remains at (and is often collectively desired as) about-ism such that they never become more than epistemological objects (Gilbert, 2016). Not only does this complicate the ability to respond by not allowing a pedagogical influence to emerge, it is further constrained by the limited time and curricular space that most programs can or do provide. This is to say nothing of the multiple pressures (and complicities) on and of science-teacher-becoming: above and beyond the complexity of coming-to-see oneself as complicit in ecological crises, of the navigating cultural myths of teaching and learning science, and the anxieties that come with often scarce teaching positions. This is to say that de/colonizing science teacher education in a permanently polluted world is not a simple, linear, or direct task.

\section{Thread 2 - Blue: The science-ethics nexus in Australian secondary schooling}

The context of my research is the 'science-ethics nexus' in Australian secondary schooling (Years 710/ages 12-15). This nexus encompasses all ways science and ethics intersect in the Australian Curriculum, which includes principally the strands of 'science' and 'general capabilities - ethical

\footnotetext{
${ }^{4}$ Through her notion of animacy theory, Mel Chen (2012) reminds us that the ways in which we come to other toxicity through attributing it to "settled categories" is not totalizing: taking toxicity seriously re-opens the potentiality to disrupt what systems of power would "wish to lock into place" (p. 159).
} 
understanding'. In addition to the Australian Curriculum, my examination also includes Years 7-10 science curriculum textbooks and interviews with beginning secondary school teachers.

The limitations of Australian school science have long been noted, such as inequality (gender, race/ethnicity, socioeconomic etc.), students' declining interest/performance, and stagnant attempts at reform (Marginson et al., 2013). What is not as often examined is the topic of ethics, and my study is part of a limited number of posthumanist and new materialist interrogations of the science-ethics nexus in schools. This undertheorizing, as noted in our introduction, is particularly surprising considering the wealth of conceptual work coming from theorists such as Barad and Haraway in relation to the scienceethics nexus more broadly. Indeed, since ethics is understood as inseparable from knowing and being, as per Barad (2007), a relational posthumanist framework necessitates that ethics be a primary concern when considering science education.

While I noted that there is a significant presence of ethical sustainability topics, and some 'hot issue' topics, such as genetic engineering and climate change, I found that the Australian curriculum, textbooks, and beginning teachers' comfort/knowledge of ethical science issues is limited; that is, not applied to all knowledge areas and lacking diversity/complexities. A particular issue I noted present in the curriculum, for instance, is how ethics is defined. The majority of philosophers and psychologists drawn on by the Australian Curriculum, Assessment and Reporting Authority (ACARA) to determine 'ethical understanding' are white and male, such as Plato, Immanuel Kant, Lawrence Kohlberg and Dennis M. McInerney (ACARA, n.d.) ${ }^{5}$.

Another significant example that presents itself in the science textbooks I analyzed is how they constitute the issue of climate change, e.g. a common anthropocentric perspective in such textbooks presents climate change as mainly an issue of human survival. Statements such as 'Is there enough variation within our species so that if things do get too hot to handle at least some of us will survive and our species will continue?' (Lofts \& Evergreen, 2014, p. 233) are representative of this positioning.

In this context, speculative fiction as method adds to the critical interrogation of the boundaries between art and science/research, in terms of emphasizing the concept of relationality. This again links back to the critique concerning the static-ness of school science; that is, school science may become static, particularly in its demarcation from other disciplines. Following from this, a concern is that research into school science may also become static via the dominance of traditional methods and stringent focus on what is rather than what might be.

${ }^{5}$ This understanding comes from analysis of supporting documents no longer available via the Australian Curriculum website. 
Thread 2 - Rouhollah and Patrick: A reciprocal model for teaching and learning computational competencies

As one of the science and technology related disciplines that is often overlooked in preparing students for the 21st century workforce, computer science in the United States does not fully reflect the diversity of the national population. Access to computer science education is very limited for non-Asian minorities, students of low socio-economic status (SES), and girls. This differential access privileges certain students over others and produces segregation in computer science education that extends to the workplace (Goode, 2007; Wilson et al., 2010). In industry, this lack of diversity is both reflected and exacerbated in top technology companies. In particular, Dowd, Malcolm, and Bensimon (2009) reported that Latinx professionals are largely absent in STEM fields, including computer science (see also Gandara \& Contreras, 2009). Many institutional barriers exist that can help account for low Latinx participation in computer science (e.g., differential access to trained computer science teachers and curricular programs).

On the other hand, there is a call for empowering and encouraging minoritized groups to pursue college degrees and careers in STEM fields in general and in CS specifically (e.g., 10 Big Ideas for Future NSF Investments, Innovative Technology Experiences for Students and Teachers [ITEST]). While this call is to address a social justice problem, it is also deeply rooted in social efficiency discourses that risk reducing education to training professional labor. A brief review shows that since 2009, an emphasis on lifelong learning has been largely replaced by college and career readiness.

A Reciprocal Model for Teaching and Learning Computational Competencies (ARMTLCC) is a three-year long project that extends existing research in the field by proposing a model to teach Computational Competencies based on the principles of culturally relevant pedagogy (Ladson-Billings, 1995). The project has implemented the model in an afterschool program for middle-school Latinx students in an urban school district in the Southeastern United States. The reciprocal nature of the model in the ARMTLCC project is that university pre-service teachers in the afterschool program and the Latinx students learn from and teach one another. The aim is for teachers to practice developing and implementing culturally relevant computational experiences through formal seminar-type classes and field experiences in the afterschool setting. The extent of teacher participation in project activities is intended to develop agency, while also engaging teachers in reflective practice aimed at examining how they can make their teaching more inclusive for urban Latinx students.

We analyzed middle school student-developed computer codes and pseudocodes in terms of their context, semantics, lexico-grammar, and phonology-graphology. We also draw on classroom observations, teachers' reflections, and interviews with parents to examine the various affective possibilities as the students worked with material objects such as robots and e-textiles, and how these were constituted as object material and program codes on their laptops as virtual material- both as posthuman things (Bennett, 2009).

Reconceptualizing Educational Research Methodology 2019, 2,3(2) Special Issue

https://journals.hioa.no/index.php/rerm/issue/view/397 
Students in the program reported fearing deportation, discrimination, and other forms of violence, and expressed concerns over xenophobic discourses amplified during the presidential election season. Many students experienced their friends and families facing deportation due to increased Immigration and Customs Enforcement raids occurring after 2016. These sentiments were evident in everyday classroom conversations as well students' problem posing projects (Aghasaleh et. al., 2018). The analysis suggested that a particular form of abstraction as a component of computational thinking (Wing, 2008) made it more difficult to translate students' lived experiences from everyday language to the machine language of coding and pseudocoding. As Guo (2018) has argued, programming adds an extra layer of complexity beyond the general ESL (English as a Second Language) barriers, since English is deeply intertwined in programming language keywords and API naming conventions. In a focus group interview, when students were asked what technology-related careers they would consider pursuing, they mentioned auto mechanic, cosmetologist, and graphic designer. Many expressed feeling smarter when they built robots and used conductive threads to make e-textile projects, and some reported that they would be more interested in working with computers as users, "like how [their] teachers would," than as developers.

This analysis navigates the ways this empowerment can continue to uphold the larger narrative of disempowerment/exclusion that Latinx learners face in relation to computer science which is why Kayumova and colleagues (2019) call for a move from empowerment to response-ability.

\section{Thread 3 - Patchworking the Theory into the Context}

\section{Thread 3 - Marc: Science teacher education, toxic politics, and teaching as slow activism \\ A permanently polluted world is one that, because of its deep alteration, reclaims the need to incite new forms of response-ability. (Liboiron et al., 2018, p. 332)}

Neither teaching science for the end of the world and implicating oneself in the inherited (neo-)colonial legacies of science, education, and science education are simple problems. Neither are they separate or separable problems; not unlike the way in which, as Rouhollah and Patrick alert above to the ways in which the project of social inclusion within the body of computer science education cannot be wholly disassociated from neoliberal logics. If, after Liboiron (2019), we take seriously the notion that "science, and research in general, has long played a role in colonial entitlement to land," we could refer to processes which (re)produce these patterns of knowing-in-being as toxicity. Toxicity's effect, "toxic harm can be understood as the contravention of order at one scale and the reproduction of order at another" (Liboiron et al., 2018, p. 336, emphasis in original). In turn, working within, against, and beyond the multiple toxic flows, forces, and intensities requires new forms of response-ability. Particularly, in response to this complex web, Liboiron suggests that we take a different temporality in our approach: 
If a permanently polluted world is characterized by chronic slow disasters incremental and attritional violence that stars no one, and fails to manifest in an event or clear-edged representation... - then a complementary form of politics is slow activism, which is also incremental and attritional, stars no one, and is not premised on nor produces events or clear-edged representation. Slow activism describes some of the political and representational tropes that eschew immediate visible and measurable outputs... that the effects of action are slow to appear or to trace... Slow activism does not have to be immediately affective or effective, premised on an anticipated result. It can just be good. (Liboiron et al., 2018, pp. 340341)

Taking seriously slow activism as a guiding concept for de/colonizing the Anthropocene in science teacher education invites a differential consideration of what Wallace (2018) refers to as pedagogies of ethico-political hesitation or what Stengers (2018) refers to as slow science (see also Higgins, Wallace, \& Bazzul, 2019). It is to take up pedagogy as partial, contigent, and situated: working to (re)open responseability rather than the dichotomous binary of ir/responsibility, which inevitably generates moments in which it is easy to let oneself off the hook. It is to work with purpose but without guarantee towards creative, critical, and caring acts that might make science momentarily stutter and place us in new relations with what and how we already know, what we do not yet know, and what we cannot yet know of the world and ourselves.

\section{Thread 3 - Blue: Creative and critical thinking-feeling-doing through speculative fiction}

My specific speculative fiction as method practice was writing the short story 'The Beforetimer' as an act of thinking-feeling-doing with relational posthumanism. In other words, I wrote this story by putting relational posthumanist concepts to work as a boundary-crossing process of discovery and openness to what might become. Taking inspiration from Jackson and Mazzei's 'thinking with theory' (2012), I extend this to include the inseparability between thinking, feeling, and doing in a process that interrogates and invigorates ideas, to allow for knowledge processes to be opened rather than foreclosed (Jackson \& Mazzei, 2013, p. 261).

In writing 'The Beforetimer', relational posthumanist concepts, such as relationality/entanglements and (anti-anthropocentric) posthumanist ethics, become in an entangled state throughout the creative process, with the intention to then assess what emerged. As mentioned earlier, this method also relates to Haraway's call to play games with string figures (SF) and what she calls "practices of worlding" (2016, p. 12). Speculative fiction is one method to renew and (re)open response-ability, to "conjugate worlds with partial connections and not universals" (Haraway, 2016, p. 13). In speculative fiction as method, there is an openness to what might become as concepts are melded and reformed, and new relationalities are speculated. Speculative fiction does not as readily constrain itself with endpoints or the 'common' sense-alities of more traditional data/conceptual work. Ambiguity and messy multiplicities are embraced. 
'The Beforetimer' is set in a post-apocalyptic world, where a small number of human survivors live in underground bunkers and are desperately trying to find a way to develop a stasis sleep so that they might sleep while the world heals. "The green things are dead and the world is dark" ('The Beforetimer'). They manage to do so but only one (non-gendered) human, Pax, wakes up alone without clear memory of who they are. "We're grasping for a future that slid out of slack fingers" ('The Beforetimer'). Pax emerges onto the surface and encounters Cedar, who is a human-nonhuman hybrid species, the Homo adaptos. "Their eyes met and the past and present clashed together silently" ('The Beforetimer'). Cedar's kind are a result of past genetic engineering, and due to their genetic differences have not only managed to survive but are now thriving in harmony with their environment.

There was a saying amongst Cedar's kind. If a tree cannot bend in the wind, it will break. In fact, it was more than a saying, but a relationship of the world that they all upheld. They also said if it has no harmony, it cannot exist. ('The Beforetimer')

Slowly regaining their memories, Pax realizes an ethical dilemma; they have the power to wake the other humans up from their stasis sleep or to not wake them up. The story ends with Pax considering this dilemma: "A thousand questions clamoured but, so far, an answer did not come" ('The Beforetimer').

\section{Thread 3 - Rouhollah and Patrick: Career readiness under erasure}

Responding to the call to move from empowerment to response-ability (Kayumova et al., 2018), we examine the ways in which Latinx students are supposed to be empowered-as the project has promised-and at the same time, how these discourses perpetuate the pragmatic values imposed by the neoliberal economy. We argue that this college and career readiness culture is conducive to racial injustice, and elaborate on our work within and against this culture.

We should make explicit that this argument must be understood as written "sous rature" (Heidegger, 1995) or what Derrida (1976) has elaborated on as "under erasure" (p. 60). Writing under erasure requires writing our argument for and against the idea of college and career readiness. Those who studied deconstruction easily identified binary logic, hierarchies, and structures that appealed to foundationalism and transcendentalism. Since we live in these structures, we are constructed by and through them, and we might gain advantages from the very structures that we criticize (Aghasaleh, 2019b). All structures were created at some point and there were advantages in the structures - at least for a group of people. However, the perpetuation of the structures and the normalization of them is problematic. Thus, Spivak (1967) defined deconstruction as "persistent critique of what one cannot not want" (p. 28).

Deconstruction is inventive or it is nothing at all; it does not settle for methodological procedures, it opens up a passageway, it marches ahead and marks a trail; its writing is not only performative, it produces rules - other conventions - for new 
performativities and never installs itself in the theoretical assurance of a simple opposition between performative and constative. Its process involves an affirmation, this latter being linked to the coming in event, advent, invention. (Derrida, 1989, p.

42)

We argue that the social efficiency discourse manifested in college and career readiness initiatives, which has roots in liberal discourses promising greater justice, freedom and progress, has become degraded within the logic of neoliberal capitalism. According to Castellano-Masias (2013), we are now experiencing a radicalization of human degradation in unexpected proportions to the point that slavery has come back to support economic growth and wealth accumulation; even though slavery is forbidden almost everywhere, the reality is that in today's world the economy is fed by slave work. While all traces of exploitation are obliterated in objects like the computer, it is not hard to make this modern slavery visible. In our case, Latinx students with immigrant backgrounds (many of them undocumented) are being encouraged or empowered to pursue technology-related careers both for their social mobility, as well as to meet the increasing need from the neoliberal economy. When they are seen as future professional workers, their college and career readiness comes to appear more important than their education as intellectual beings. This level of dehumanization is the reason that Carmen Guerrero refers to immigrants as potential subjects for neoliberal slavery (Moya, 2018).

\section{Thread 4 - Productions of and Possibilities for Response-Ability}

\section{Thread 4 - Marc: Recasting the "great straw debate" with Liboiron}

Disposability is not the result of the bad behavior of some individuals choosing to buy some things and not others. Consumer choice as a concept makes no sense in many places. ...Disposable plastics are simply not possible without colonizer access to land. The end of colonialism will result in the end of plastic disposability. (Liboiron, 2018)

With the aforementioned confluences of forces, flows and intensities, coming to bear onto science teacher education (e.g., cultural myths of science teacher education; ethico-political work of coming-tosee oneself as complicit; limited time, space, and resources, etc.), there is a need to strategically work with/in the possible possibilities that are present (while re-imagining and seeking out alternative futures): as Rouhoullah and Patrick suggest, a putting under erasure of the critical and complicit space inhabited. In other words, I needed and continue to seek out a response-able pedagogy that already connected to where teachers were at that simultaneously held the potential to both connect them to something beyond and gently reveal the (neo-)colonial shape and form of knowledge already held and enacted through already held mores of environmental responsibility. Here, the notion of potential is significant as "ethics, rather than an anticipated result, is at the core of slow activism" (Liboiron et al., 2018, p. 342). 
In the wake of the banning of single-use straws and the ways in which it was hotly debated in the public sphere, I invited students to read Liboiron's (2018) short and punchy piece in Teen Vogue that tackles plastics as a form of waste colonialism (i.e., how waste disposal is tied up in "a system of domination that grants a colonizer access to land for the colonizer's goals" [Liboiron, 2018]) to consider the ways in which (neo-)colonialism might play out in our already existing relations to single-use plastic straws: What are some of the taken-for-granted ideas and ideals about plastics that circulate in society? Where do these come from? What are the socio-cultural, economic, and political impacts of single-use straws, as well as their ban? What does Liboiron invite us to consider with respect to our own individual and collective relations to plastic (e.g., within and beyond the logics of consumer choice)? Liboiron's work provides many provocations that were productive (e.g., pollution as colonialism, nature and plastic not being dichotomous; see also Liboiron, 2019), but one that affected many (holding that affect does not immediately materialize: for some, end of term writing was were an effect emerged) was the consideration of plastic as kin:

Plastic is our kin, it's our relation. It's from ancestors - organic ancestors from a long time ago. And if you neglect your relations to that, then you're bad kin. Even when plastic is misbehaving, which means it's being bad kin, you can still do good kinship with bad kin. And you know this. You have an asshole uncle somewhere. He might be bad kin but you still call him on his birthday, or bail him out of jail depending on what kind of bad kin he is. The same thing is true of plastics. I spend a lot of time with plastics. I do a lot of care work for plastics. I make sure that they are cleaned properly and I look at them a long time, and when I look at them, and I look at them in aggregate, I learn things about where they've been, and how they might have got there, and what their journeys might have been like, and where they might be going, because they're going to go for a long time. (Liboiron, 2019)

If science education relentlessly needs to reimagine and resist the ways in which the (neo-)colonial relations we are always already in, the language of kinship is a subtle, slow, but significant way of redirecting the ways in which such multiplicitous forms of domination remain both palatable and possible (see Bang \& Marin, 2015).

\section{Thread 4 - Blue: Posthumanist productions of speculative fiction as method}

There are four main ways that speculative fiction as method, as an enactment of relational posthumanism, helps evoke renewed possibilities in relation to the science-ethics nexus in schools.

The first prospect is developing posthumanist ethics as a central component in school science and as something that is never separate from knowledge. In writing 'The Beforetimer', the thinking-feelingdoing of posthumanist ethics lead to the consideration of a human-nonhuman hybrid species succeeding humanity's dominance of the planet. To critically renew ethical becoming, it is necessary not only to 
critically question anthropocentrism, but to consider alternatives and the often unimagined. What would school science look like if a posthumanist ethics is central to all aspects of science learning?

The second possibility is also centering relationality, which would necessitate a move away from learning topics in isolation from each other, or from sociocultural contexts. For example, learning about 'the atom' would require consideration of the history and sociocultural contexts surrounding the ethical knowledge production of 'the atom', i.e. atomic bombs. In speculative fiction, the demarcations between science, art and other 'disciplines' are dissolved. There is a fusion between the world as it is, considerations of science and technology, and creative production. Considerations of what science is and how we define it is an intrinsic aspect of writing speculative fiction as method. In creative research practice, binary logics are put under intense pressure and this leads naturally to critical consideration of binary logics within the research context.

The third possibility is centering 'diverse ways-of-knowing', which requires open acknowledgement of cultural biases/homogeny, inequities, and diverse approaches to knowledge production as responseability. One example, as Marc raised earlier, being the consideration of Indigenous ways-of-knowingbeing. Although it is difficult and fraught to identify cultural lineages, given the complexities and entangled becoming of knowledge production, there are clear cultural implications of understanding science, human-nonhuman relationships, and the environment. The state of the world 'as it is' is in a state of crisis, in which culturally entangled epistemologies about the environment, climate, and humanity are currently paving the way for a bleak future for humanity, as is depicted in 'The Beforetimer'. According to scientific consensus, this is a highly plausible eventuality unless there is significant social change (Allen et al., 2018).

The fourth possibility, to circle back, is to utilize creative approaches within schooling, such as students drawing on speculative fiction to consider ethical science issues. Creative research production in research smoothly relates to considerations of where else such creative thinking-feeling-doing processes can (re)open possibilities. As put by Jennifer Gabrys and Kathryn Yusoff (2012, p. 1), towards artsscience connections relating to climate change, processes that cross disciplinary boundaries enact "sites of encounter, transformations, uncertainties, future scenarios, material conditions and political practices".

To illustrate how these four possibilities might become in school science, I offer the following scenario. In an Australian Year 8 class, the students are studying not 'science' but rather 'ethical imagination' as it connects with various scientific topics. They begin this examination at a nature reserve, with an Indigenous guide, which is a continuation of their explorations into Indigenous ways-of-knowing-being. Their guide takes them through some aspects of the local Indigenous language group's connections to this land. Students are invited to share what they know about the significance of their own cultural backgrounds in thinking about how humans relate to 'environments' and other species. 
Students next read a speculative fiction short story in their textbooks about a genetically modified human. This textbook is about science issues but it makes ethics central. Such content is also expressly linked with sociocultural phenomena, as well as other subjects, such as history. In this exercise, the students are encouraged to put themselves into the story, to think about diverse ethical considerations, and to come up with alternative endings. They are also asked to draw on their developing understanding of DNA. They share their stories with each other and the teacher guides them to discuss the differences between their stories according to their backgrounds, their identities, and how they feel about gene technology and the emotional experience of the story.

This scenario touches on only some ways in which school science could develop more response-ability, towards a more livable world for all, in an enactment of relational posthumanist concepts. Further (creative) work in this area could manifest such possibilities more clearly as well as offer additional possibilities.

\section{Thread 4 - Rouhollah and Patrick: Codes, pseudocodes, and critical student becomings}

Popkewitz (1998) stated that, "populational reasoning constructs our understanding of the way children learn, of school achievement, and the social and psychological attributes presumed to cause school failure" (p. 26). Latinx students were seen as an at-risk population. For instance, Latina girls are subjects for hypersexualization (Brooks, 2010; Molina-Guzmán, 2010) that involves fear and need for more discipline. The term "at-risk youth" was more frequently used in the wake of the 1983 publication of the policy report A Nation At Risk. The report cautioned that America's way of life was threatened by a "rising tide of mediocrity" within the school system. The term "at risk" suggested a focus on prevention and intervention, in the form of social services, tutoring and related programs. According to the Ngram, it seems to have risen in popularity just as "juvenile delinquent" declined.

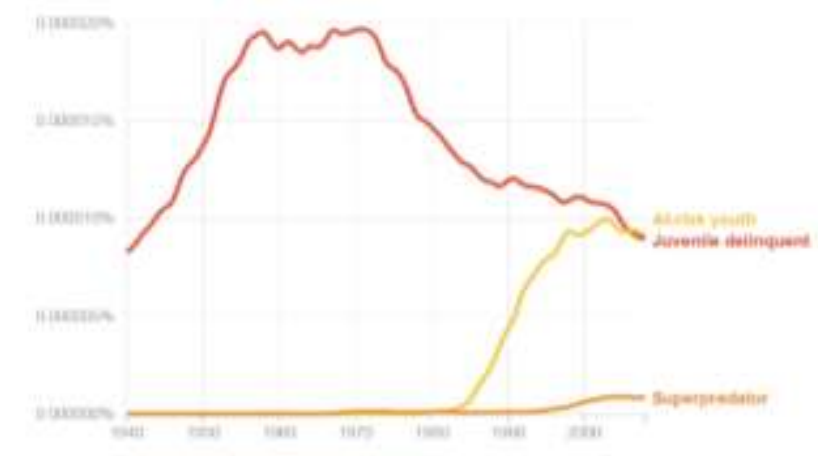

Figure 1. Ngram Google Chart of Word Frequencies

(at-risk youth, juvenile delinquent, superpredator) 
While delinquent referred to a state of being, at risk suggested a vulnerable person in need of help. Placier (1993) argued that at risk became a buzzword because it was vague enough to be defined broadly or narrowly, depending on the purpose. However, Bernstein and Mason both point out that "at risk" focused on the negative. Indeed, this negative connotation becomes a useful tool for neoliberal discourses to leverage college and career readiness initiatives as beneficent endeavors aimed at improving the lived experiences of those who are labelled with it. Meanwhile, such initiatives strongly emphasize conformity to activities and behaviors that provide more direct benefit to those supporting them than to those participating in them.

Such labels are manifestations of underlying attitudes and beliefs that become problematic when considering ways to educate learners of color in ways that can meet their "needs" (and not necessarily their interests or desires). Teachers made their special education referrals based on their perceptions, such as whether they believed a student is teachable or non-threatening (Harry \& Anderson, 1994). Given teachers' perceptions of them as threatening, at-risk, or distracting, inevitably Latinx students along with Black boys represented a large number of those referred for removal from the general education environment and funneled instead into a challenged or disruptive category. This is a message that students and families receive implicitly and explicitly from school and media that perpetuates and institutionalize the belief that Latinx are 'at-risk' which has consequences on their self-esteem and career planning.

This obsession with dehumanizing Black males as criminals, Latinxs as at-risk, and girls as sexual objects created much surveillance and suspicion (Brunson \& Miller, 2006). Ladson-Billings (2011) suggested that the symbolic message attached to young Black males in popular culture puts society in a love-hate relationship with African American males. As Black boys reached school age, they were no longer seen as cute, but are viewed as men with criminal capabilities. Similarly, Latina girls were viewed as women. Schools respond to this fear by increasing the control over these bodies. Thus, schools mimicked prison with dress codes (e.g., no hoodies, no spaghetti strap tops, etc. allowed), limiting or prohibiting social interaction between students in hallways and cafeterias, removing disruptive students from classrooms, and regulating students' recess or free time in a manner reminiscent of a prison yard. These actions were narrated by news stories, such as the reports in Milledgeville, Georgia of a six-year-old elementary school student who was handcuffed and arrested after she allegedly threw a tantrum (Clausing, 2012). Narratives crafted through news stories also worked to further oppress the students in our study as during their participation, much of society's perception of their families and communities was shaped through media narratives around immigration; narratives that often fail to include the actual accounts of Latinx people, even more so Latinx youth. The need to counter those narratives and develop their own resistance stories emerged as critical and consistent across multiple computational activities. Learners often positioned Trump and immigration issues in negative ways and agents within the products would push back against those oppressive forces, even invoking personalities not typically cast in such perspectives, such as Joaquin "El Chapo" Guzman (Aghasaleh et al., 2018). 


\section{Conclusion}

When applied to notions of justice in education, response-ability invokes the right to epistemological and ontological heterogeneities, all the different ways by which we, communities of different ethnicities, languages, and locations understand ourselves, our relations, and the world around us. (Kayumova et al., 2019, p. 227)

As Kayumova and colleagues (2019) invite us to consider, response-ability is not only about refusing and resisting the systems of dominance that have Othered human, other-than-human, and more-thanhuman beings through the techno-scientific construction of knowledge. Rather, the shift from empowerment to response-ability is not one that is teleological, rooted in binary logics, or progressive: it is also a recommitting to empowerment that (post-)critically attends to its own complicities and ways in which it always already becomes disempowering to those it attempts the response (see Ellsworth, 1989). Further, it also includes re(con)figuring the scene of address so that those whose ability to respond to systems of power have been dampened by such might also respond. Importantly, and significantly, this means making space for and relationally drawing from this heterogeneous multiplicity: critically and creatively finding new ways of collectively being together. As they state,

an inquiry into justice cannot be merely reduced to distributive notions of power and instrumentalist discourse. If anything, empowerment must be about supporting and legitimizing local communities' knowledge base, skills and power to contribute to decision making and their right to respond, response-ability, to the issues.

(Kayumova et al., 2019, p. 224)

In concluding this paper, we recommit to the importance of "collective organizing, reconfiguring, and reimagining" (Kayumova et al., 2019, p. 212) that begins from attending to criticality from science and technology's margins rather than an a ubiquitous yet somehow depoliticized and under-theorized notions of empowerment that is formulated within its center. In turn, in order to account for and be accountable to difference, figurations of response-ability must (and will) always take shape differently as they are always already in relation to the particular relations that co-constitute them. This will require that the orientations, theories, practices, and ethics with which we approach the problems and possibilities anew in critical and creative ways: "to make science education more relevant, responseable, and reflexive in its efforts to be equitable, inclusive, and robust requires an integration of 'new' and alternative frameworks" (Kayumova et al., 2019, p. 212). In (re)presenting our differential accounts we re- and un-weave together methodological threads to create a patchwork of string figurations that disperse and deploy contingent and situated making-withs: Marc thought with Liboiron to differentially engage what it means to de/colonize science teacher education with an Indigenous STS conception of pollution as colonization; Blue scrutinized the science-ethics nexus in secondary Australian schools with speculative fiction to creatively re-envision how we define and engage with ethics; Rouhollah and Patrick deconstructed the implicit post-human curricula in computer science in which computer codes, pseudocodes, hardware, and software become entangled with "at-risk" discourses and social efficiency 
to create dis/empowering computational experience for Latinx learners. Working with purpose, but without guarantee, is par for the course when it comes to such enactments of response-ability; we posit that plurality is a strength rather than a liability in the work of coming together differentially.

\section{References}

Allen, M.R., O.P. Dube, W. Solecki, F. Aragón-Durand, W. Cramer, S. Humphreys, M. Kainuma, J. Kala, N. Mahowald, Y. Mulugetta, R. Perez, M. Wairiu, \& K. Zickfeld. (2018). Framing and context. In V. Masson-Delmotte, P. Zhai, H.-O. Pörtner, D. Roberts, J. Skea, P.R. Shukla, A. Pirani Shukla, W. Moufouma-Okia, C. Péan, R. Pidcock, S. Connors, J.B.R. Matthews, Y. Chen, X. Zhou, M.I. Gomis, E. Lonnoy, T. Maycock, M. Tignor, \& T. Waterfield (Eds.), Global warming of $1.5^{\circ} \mathrm{C}$. An IPCC special report on the impacts of global warming of $1.5^{\circ} \mathrm{C}$ above pre-industrial levels and related global greenhouse gas emission pathways, in the context of strengthening the global response to the threat of climate change, sustainable development, and efforts to eradicate poverty (pp. 4991). Retrieved from https://www.ipcc.ch/sr15/

Australian Curriculum, Assessment and Reporting Authority. (n.d.). Ethical understanding. Retrieved from http://v7-5.australiancurriculum.edu.au/GeneralCapabilities/Pdf/Ethic understanding

Association of Canadian Deans of Education. (2010). Accord on Indigenous education. Retrieved from www.csse.ca/ACDE

Association of Canadian Deans of Education. (2018). Visioning environmental sustainability education in teacher education. Panel presentation at 2018 Canadian Society for the Study of Education (CSSE) Annual Meeting: Gathering Diversity, Regina, SK.

Aghasaleh, R. (Ed.) (2019a). Children and Mother Nature: Storytelling for a Glocalized Environmental Education. Leiden, Netherlands: Brill Sense. https://doi.org/10.1163/9789004399822

Aghasaleh, R. (2019b). (Un)building the Wall Reinventing Ourselves as Others in the Post-truth Era. Journal of Curriculum Theorizing, Special Issue on Curriculum Theorizing in Post-truth Era, 34(3), 1-11.

Aghasaleh, R., Enderle, P., Puvirajah, A. (2019). From computational thinking to political resistance: Reciprocal lessons from urban Latinx middle school students. Journal of Activist Science and Technology Education, Special Issue on Topologies of Activism, 10(1), 29-44. https://doi.org/10.33137/jaste.v10i1.32915

Aghasaleh, R., Enderle, P., Puvirajah, A., Boehnlein, A., Rickard, J., Bornstein, J., \& Hendrix, R. (2018). Computational problem-posing with urban Latinx youth. Curriculum and Teaching Dialogue: Vol. 20\# 1 \& 2, 143.

Bang, M., \& Marin, A. (2015). Nature-culture constructs in science learning: Human/non- human agency and intentionality. Journal of Research in Science Teaching, 52(4), 530- 544. https://doi.org/10.1002/tea.21204 
Barad, K. (1996). Meeting the universe halfway: Realism and social constructivism without contradiction. In Feminism, science, and the philosophy of science (pp. 161-194). Springer, Dordrecht. https://doi.org/10.1007/978-94-009-1742-2_9

Barad, K. (2007). Meeting the universe halfway: Quantum physics and the entanglement of matter and meaning. Durham, NC: Duke University Press. https://doi.org/10.1215/9780822388128

Barad, K. (2010). Quantum entanglements and hauntological relations of inheritance: Dis/continuities, spacetime enfoldings, and justice-to-come. Derrida Today, 3(2), 240- 268. https://doi.org/10.3366/drt.2010.0206

Barr, V., \& Stephenson, C. (2011). Bringing computational thinking to K-12: what is Involved and what is the role of the computer science education community? ACM Inroads, 2(1), 48-54. https://doi.org/10.1145/1929887.1929905

Bennett, J. (2009). Vibrant matter: A political ecology of things. Duke University Press. https://doi.org/10.1215/9780822391623

Bleich, D. (2001). The materiality of language and the pedagogy of exchange. Pedagogy, 1(1), 117-141. https://doi.org/10.1215/15314200-1-1-117

Brooks, S. (2010). Hypersexualization and the dark body: Race and inequality among black and Latina women in the exotic dance industry. Sexuality Research and Social Policy, 7(2), 70-80. https://doi.org/10.1007/s13178-010-0010-5

Brunson, R. K., \& Miller, J. (2006). Young Black men and urban policing in the United States. British Journal of Criminology, 46(4), 613-640. https://doi.org/10.1093/bjc/azi093

Bullock, E. (2017) Only STEM can save us? Examining race, place, and STEM education as property. Educational Studies, 53(6), 628-641. https://doi.org/10.1080/00131946.2017.1369082

Castellano-Masias, P. (2013). Neoliberal slavery and the imperial connection. Sinergia E InnovacióN, 1(08). Consultado de http://revistas.upc.edu.pe/index.php/sinergia/article/view/90

Cedillo, S. (2018). Beyond Inquiry: Towards the Specificity of Anti-Blackness Studies in STEM Education. Canadian Journal of Science, Mathematics and Technology Education, 18(3), 242-256. https://doi.org/10.1007/s42330-018-0025-0

Chen, M. Y. (2012). Animacies: Biopolitics, racial mattering, and queer affect. Durham, NC: Duke University Press. https://doi.org/10.1215/9780822395447

Chen, G. \& Buell, J. (2018) Of models and myths: Asian(Americans) in STEM and the neoliberal racial project. Race Ethnicity and Education, 21(5), 607-625. https://doi.org/10.1080/13613324.2017.1377170

Chesky, N. Z., \& Wolfmeyer, M. R. (2015). Philosophy of STEM education: A critical investigation. New York, NY: Springer. https://doi.org/10.1057/9781137535467

Clausing, J. (2012). Georgia handcuffing of kindergartner for tantrum renews school policing debate. Retrieved October 22, 2012 from http://www.huffingtonpost.com/2012/04/18/ga-handcuffcase-renews-s_0_n_1434245.html.

Davis, H., \& Todd, Z. (2017). On the Importance of a Date, or Decolonizing the Anthropocene. ACME: An International E-Journal for Critical Geographies, 16(4).

Reconceptualizing Educational Research Methodology 2019, 2,3(2) Special Issue https://journals.hioa.no/index.php/rerm/issue/view/397 
Daza, S. L. (2013). A promiscuous (feminist) look at grant-science: How colliding imaginaries shape the practice of NSF policy. International journal of qualitative studies in education, 26(5), 580-598. https://doi.org/10.1080/09518398.2013.786844

de Freitas, E., Lupinacci, J., \& Pais, A. (2017). Science and technology studies $\times$ educational studies: Critical and creative perspectives on the future of STEM education. Educational Studies, 56(6), 551-559. https://doi.org/10.1080/00131946.2017.1384730

Derrida, J. (1976). Of Grammatology, trans. Gayatri Chakravorty Spivak.

Derrida, J. (1989). Edmund Husserl's origin of geometry: An introduction. U of Nebraska Press.

Derrida, J. (1990). Some statements and truisms about neologisms, newisms, postisms, parasitisms, and other small seismisms. The states of theory, 63-94.

Dowd, A. C., Malcom, L. E., \& Bensimon, E. M. (2009). Benchmarking the success of Latina and Latino students in STEM to achieve national graduation goals. Los Angeles, CA: Center for Urban Education.

Ellsworth, E. (1989). Why doesn't this feel empowering? Working through the repressive myths of critical pedagogy. Harvard educational review, 59(3), 297-325. https://doi.org/10.17763/haer.59.3.058342114k266250

Freire, P. (1968). Pedagogy of the Oppressed. 1972. Trans. Myra Bergman Ramos. New York: Herder. Gabrys, J., \& Yusoff, K. (2012). Arts, sciences and climate change: Practices and politics at the threshold, Science as Culture, 21(1), 1-24, https://doi.org/10.1080/09505431.2010.550139

Gandara, P. C., \& Contreras, F. (2009). The Latino education crisis: The consequences of failed social policies. Cambridge, MA: Harvard University Press.

Gilbert, J. (2016). Transforming Science Education for the Anthropocene-Is It Possible?. Research in Science Education, 46(2), 187-201. https://doi.org/10.1007/s11165-015-9498-2

Goode, J. (2007). If you build teachers, will students come? The role of teachers in broadening computer science learning for urban youth. Journal of Educational Computing Research, 36(1), 65-88. https://doi.org/10.2190/2102-5G77-QL77-5506

Goode, J. (2008). Increasing diversity in K-12 computer science education: Lessons from the field. Proceedings of the 38th SIGCSE Technical Symposium on Computer Science Education, 40(1), 362-371. https://doi.org/10.1145/1352135.1352259

Grover, S., \& Pea, R. (2013). Computational thinking in K-12: A review of the state of the field. Educational Researcher, 42(1), 38-43. https://doi.org/10.3102/0013189X12463051

Guo, P. J. (2018, April). Non-native English speakers learning computer programming: Barriers, desires, and design opportunities. In Proceedings of the $2018 \mathrm{CHI}$ Conference on Human Factors in Computing Systems (p. 396). ACM. https://doi.org/10.1145/3173574.3173970

Haraway, D. (1991). Simians, Cyborgs and Women: The Reinvention of Women. London: Free Association Books.

Haraway, D. (2016). Staying with the trouble: Making kin in the Chthulucene. Duke University Press. https://doi.org/10.1215/9780822373780

Reconceptualizing Educational Research Methodology 2019, 2,3(2) Special Issue https://journals.hioa.no/index.php/rerm/issue/view/397 
Heidegger, M. (1995). The fundamental concepts of metaphysics: World, finitude, solitude. Indiana University Press. https://doi.org/10.2307/j.ctvswx8mg

Henderson, P. B., Cortina, T. J., \& Wing, J. M. (2007). Computational thinking. Paper presented at the ACM SIGCSE Bulletin. https://doi.org/10.1145/1227504.1227378

Heybach, J. \& Pickup, A. (2017) Whose STEM? Disrupting the gender crisis within STEM. Educational Studies, 53(6), 614-627. https://doi.org/10.1080/00131946.2017.1369085

Higgins, M. (2017). Post-qualitative mo(ve)ments: Concluding remarks on methodological responseabilities and being wounded by thought. Reconceptualizing Educational Research Methodology, 8(3), 89-101. https://doi.org/10.7577/rerm.2553

Higgins, M. (2019). Pursuing response-ability in de/colonizing science education. In J. Bazzul \& C. Siry (Eds.), Critical Voices in Science Education: Narratives of Hope and Struggle (pp. 223-233). New York: Springer. https://doi.org/10.1007/978-3-319-99990-6_21

Higgins, M., \& Kim, E.J. (2019). De/colonizing methodologies in science education: Rebraiding research theory-practice-ethics with Indigenous theories and theorists. Cultural Studies of Science Education, 14(1), 111-127. https://doi.org/10.1007/s11422-018-9862-4

Higgins, M., Madden, B., Bérard, M.-F., Lenz Kothe, E., \& Nordstrom, S. (2017). De/signing research in education: Patchwork(ing) methodologies with theory. Educational Studies, 43(1), 16-39. https://doi.org/10.1080/03055698.2016.1237867

Higgins, M., \& Tolbert, S. (2018). A syllabus for response-able inheritance in science education. Parallax, 24(3), 273-294. https://doi.org/10.1080/13534645.2018.1496579

Higgins, M., Wallace, M., \& Bazzul, J. (2018). Disrupting and displacing methodologies in STEM education: From engineering to tinkering with theory for eco-social justice. Canadian Journal of Science, Mathematics and Technology Education, 18(3), 187-192. https://doi.org/10.1007/s42330-018-0020-5

Higgins, M., Wallace, M., \& Bazzul, J. (2019). Staying with the trouble in science education. In C. Taylor and A. Bayley (Eds.), Posthumanism and Higher Education: Reimagining Pedagogy, Practice and Research (pp. 155-164). Basingstoke, UK: Palgrave Macmillan. https://doi.org/10.1007/978-3030-14672-6_9

Holdren, J., Lander, E., \& Varmus, H. (2010). Prepare and inspire: $k$-12 education in science, technology, engineering and math education for America's future: The President's Council of Advisors on Science and Technology, Office of Science and Technology Policy.

Jackson, A. Y., \& Mazzei, L. A. (2012). Thinking with theory in qualitative research: Viewing data across multiple perspectives. New York, NY: Routledge. https://doi.org/10.1177/1077800412471510

Jackson, A. Y., \& Mazzei, L. A. (2013). Plugging one text into another: Thinking with theory in qualitative research. Qualitative Inquiry, 19(4), 261-271.

Jackson, A. Y., \& Mazzei, L. A. (2017). Thinking with theory: A new analytic for qualitative inquiry. In N. K. Denzin \& Y. S. Lincoln (Eds.), The Sage Handbook of Qualitative Research (5th ed., pp. 717-727). Thousand Oaks, CA: Sage.

Reconceptualizing Educational Research Methodology 2019, 2,3(2) Special Issue https://journals.hioa.no/index.php/rerm/issue/view/397 
Kafai, Y. B., Fields, D. A., \& Burke, W. Q. (2010). Entering the clubhouse: Case studies of young programmers joining the online Scratch communities. Journal of Organizational and End User Computing (JOEUC), 22(2), 21-35. https://doi.org/10.4018/joeuc.2010101906

Kayumova, S., McGuire, C. J., \& Cardello, S. (2019). From empowerment to response-ability: rethinking socio-spatial, environmental justice, and nature-culture binaries in the context of STEM education. Cultural Studies of Science Education, 14(1), 205-229. https://doi.org/10.1007/s11422-018-9861-5

Kayumova, S., Zhang, W., \& Scantlebury, K. (2018). Displacing and disrupting colonizing knowledgemaking-practices in science education: Power of graphic-textual illustrations. Canadian Journal of Science, Mathematics and Technology Education, 18(3), 257-270. https://doi.org/10.1007/s42330-018-0030-3

Kleinman, A. (2012). Intra-actions. Mousse, 34, 76-81. Retrieved from http://moussemagazine.it/ Kuokkanen, R. (2007). Reshaping the university: Responsibility, Indigenous epistemes, and the logic of the gift. Vancouver, BC: UBC Press.

Ladson-Billings, G. (1995). Toward a theory of culturally relevant pedagogy. American Educational Research Journal, 32(3), 465-491. https://doi.org/10.3102/00028312032003465

Ladson-Billings, G. (2011). Boyz to men? Teaching to restore Black boys' childhood. Race, Ethnicity and Education, 14(1), 7-15. https://doi.org/10.1080/13613324.2011.531977

Lather, P., \& St. Pierre, E. A. (2007). Postpositivist new paradigm inquiry. In P. Lather, Getting lost: Feminist efforts toward a double(d) science (p. 164). Albany: State University of New York Press.

Latour, B. (2004). Why has critique run out of steam? From matters of fact to matters of concern. Critical inquiry, 30(2), 225-248. https://doi.org/10.1086/421123

Lewis, S. L., \& Maslin, M. A. (2015). Defining the anthropocene. Nature, 519(7542), 171. https://doi.org/10.1038/nature14258

Liboiron, M. (2018). How plastic is a function of colonialism. Teen Vogue. Retrieved from https://www.teenvogue.com/story/how-plastic-is-a-function-of-colonialism.

Liboiron, M. (2019). Anti-colonial science \& the ubiquity of plastic. Frankinterviews. Retrieved from http://franknews.us/interviews/206.

Liboiron, M., Tironi, M., \& Calvillo, N. (2018). Toxic politics: Acting in a permanently polluted world. Social studies of science, 48(3), 331-349. https://doi.org/10.1177/0306312718783087

López Moya, E. (2018, April 16). "Immigrants are slaves to neoliberalism". Retrieved April 16, 2019, from https://aldianews.com/articles/leaders/immigrants-are-slaves-neoliberalism/52343

Lofts, G., \& Evergreen, M. J. (2014). Science quest 10 for Victoria (Australian curriculum edition). Australia: John Wiley \& Sons Australia, Ltd.

Lupinacci, J. \& Wolfmeyer, M. (2018). (Re)Considering STEM education: Continuing the critical opposition and proposition. Critical Education, 9(16), 1-4.

MacLure, M. (2013). Researching without representation? Language and materiality in post-qualitative methodology. International journal of qualitative studies in education, 26(6), 658-667. https://doi.org/10.1080/09518398.2013.788755

Reconceptualizing Educational Research Methodology 2019, 2,3(2) Special Issue https://journals.hioa.no/index.php/rerm/issue/view/397 
Marginson, S., Tytler, R., Freeman, B., \& Roberts, K. (2013). STEM: country comparisons. Retrieved from https://acola.org.au/wp/PDF/SAF02Consultants/SAF02_STEM_\%20FINAL.pdf

McKinley, E. (2001). Cultural diversity: Masking power with innocence. Science Education, 85(1), 74-76. https://doi.org/10.1002/1098-237X(200101)85:1<74::AID-SCE8>3.0.CO;2-U

Molina-Guzmán, I. (2010). Dangerous curves: Latina bodies in the media. NYU Press. https://doi.org/10.18574/nyu/9780814757352.001.0001

Moya, E. L. (2018, April 16). "Immigrants are slaves to neoliberalism". Retrieved September 16, 2019, from https://aldianews.com/articles/leaders/immigrants-are-slaves-neoliberalism/52343.

NGSS Lead States. (2013). Next Generation Science Standards: For states, by states. Washington, DC: The National Academies Press.

Parks, A. N. (2009). Doomsday Device: Rethinking the Deployment of the 'Achievement Gap' in Equity Arguments. For the Learning of Mathematics, 29(1), 14-19.

Placier, M. L. (1993). The semantics of state policy making: The case of "at risk". Educational Evaluation and Policy Analysis, 15(4), 380-395. https://doi.org/10.2307/1164536

Popkewitz, T. S. (1998). Struggling for the Soul. The Politics of Schooling and the Construction of the Teacher. New York, NY: Teachers College Press.

Sengupta, P., Kinnebrew, J. S., Basu, S., Biswas, G., \& Clark, D. (2013). Integrating computational thinking with K-12 science education using agent-based computation: A theoretical framework. Education and Information Technologies, 18(2), 351-380. https://doi.org/10.1007/s10639-0129240-x

Spivak, G. C. (1976). Preface: Of Grammatology (Translated by Gayatri Chakravorty Spivak from De la Grammatologie, 1967).

Spivak, G. C. (1994). Responsibility. boundary 2, 21(3), 19-64 https://doi.org/10.2307/303600

Stengers, I. (2018). Another science is possible: A manifesto for slow science. Cambridge: Polity.

Tolbert, S., \& Bazzul, J. (2017). Toward the sociopolitical in science education. Cultural Studies of Science Education, 12(2), 321-330. https://doi.org/10.1007/s11422-016-9737-5

Wallace, M. F. G. (2018). The paradox of un/making science people: Practicing ethico-political hesitations in science education. Cultural Studies of Science Education, 13(4), 1049-1060. https://doi.org/10.1007/s11422-017-9831-3

Wallace, M., Higgins, M., \& Bazul, J. (2018). Taking Nature seriously: Contours of possibility in science education. Canadian Journal of Science, Mathematics and Technology Education, 18(3), 199-209. https://doi.org/10.1007/s42330-018-0026-z

Whyte, K. P. (2018). Indigenous science (fiction) for the Anthropocene: Ancestral dystopias and fantasies of climate change crises. Environment and Planning E: Nature and Space, 2514848618777621.

Wilson, C., Sudol, L. A., Stephenson, C., \& Stehlik, M. (2010). Running on empty: The failure to teach K-12 computer science in the digital age. New York, NY: The Association for Computing Machinery and the Computer Science Teachers Association.

Reconceptualizing Educational Research Methodology 2019, 2,3(2) Special Issue https://journals.hioa.no/index.php/rerm/issue/view/397 
Wing, J. M. (2006). Computational thinking. Communications of the ACM, 49(3), 33-35. https://doi.org/10.1145/1118178.1118215

Wolfmeyer, M. \& Lupinacci, J. (2017). (Re)considering STEM education: Interrupting an omnipresent discourse. Critical Education, 8(15), 1-4.

Verlie, B. (2017) Rethinking climate education: Climate as entanglement. Educational Studies, 53(6), 560572. https://doi.org/10.1080/00131946.2017.1357555

Reconceptualizing Educational Research Methodology 2019, 2,3(2) Special Issue

https://journals.hioa.no/index.php/rerm/issue/view/397 